\title{
酸素電極用活性炭のぬれ特性
}

堀田紀好* $\cdot$ 藤田隆夫

(平成元年 7 月 12 日受理)

\section{Wettability of Activated Carbon for Using as an Oxygen Electrode}

Kiyoshi Horita and Takao Fujita

Department of Industrial Chemistry,

Faculty of Engineering, Fukui University, Bunkyo, Fukui-shi 910 JAPAN

This experiment was carried out for the improvement of wettability of oxygen electrode with activated carbon. Adsorption isotherms of water and benzene on the two kinds of carbons which were charcoal and PVC char activated with ammonia gas at $950^{\circ} \mathrm{C}$ were determined to evaluate wettability and pore structure, respectively. It has been found that water adsorption isotherms for the activated carbons are typically S-shaped and that the micropore in these samples plays an important role on the adsorption of water. In the range of low relative pressure the amount of water adsorbed on the sample was proportional to relative pressure. The surface of the activated charcoal was more hydrophilic than that of the activated PVC char. Wettability of the activated carbons was dependent on the amount of surface oxides on these samples. The adsorption mechanism of water onto the activated carbon would be explained by using the cluster model and the condensation of water molecules.

KEYWORDS: Wettability, Activated carbon, Oxygen electrode

\section{1. 緒 言}

炭素材料の狆特性はきわめて重要な界面現象の一つ である。たとえば, 酸素一水素燃料電池 ${ }^{1)}$ や空気湿電池 2) あるいは最近脚光を浴びてきた工業電解用拡散電極了),

4)など, 気体を電池活物質として用いる場合には, ての 活物質を保持するために多孔性炭素材料が電極として使 用されるが, ここで, 活物質である気体が電極上で電気 化学的反応を起てすためには気体, 液体, 固体の三者が 共存するいわゆる三相界面をできるだけ多く存在させる 必要がある。この三相界面の保持には電解液による炭素 福井大学工学部工業化学教室: $\mathbf{T} 910$ 福井市文京三丁目 $9-1$
材質のぬれ現象が大きな因子となる。 本研究では, 酸素ガス拡散型の電極材料として用いる 二種類の活性炭すなわち木炭抢よびポリ塩化ビニル炭(以 下 PVC 炭と略記する) をそれぞれアンモニアガスによ り活性化した試料についての水蒸気吸着等温線の測定に 基づいて, 活性炭の好特性を検討するとともにベンゼ ン吸着等温線より評価した活性炭の細孔構造之の関連性 についても考察を加えた結果, 興味ある知見を得たので 報告する。

\section{2. 実験方法}

\section{1 原料炭の調製}

木炭試料は市販のナラ木炭を粉砕し, 100〜200メッシ 
ユの粒群にふるい分けたあのを使用した。灰分を除去す るため, 試料を共沸塩酸ととあに 1 時間惹沸後, 万過し 塩化物イオンが検知されなくなるまでイオン交換水で洗 浄, 乾燥した。得られた試料中の灰分含有量は $0.37 \%$ で

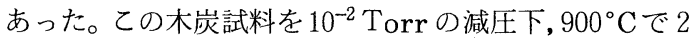
時間加熱処理して標準化したものを原料木炭とした。 $\mathrm{PVC}$ 炭試料は既報 ${ }^{5)}$ 之同様, PVC粉末を $150 \sim 170^{\circ} \mathrm{C}$ の 熱濃硫酸中で50時間炭化処理し，ついで，炭化物をろ別 後, 温水を用いて十分洗浄, 乾燥した。乙の炭化物を窒 素気流中, $900^{\circ} \mathrm{C}, 2$ 時間処理して炭化脱塩酸を完全に したのち, 120〜200メッシュの粒群にふるいわけたもの を使用した。

\section{2 原料炭の活性化}

原料炭の活性化は, アンモニアガスを用い, Fig. 1 亿 示す装置により行なった。すなわち, 試料約 $3 \mathrm{~g}$ を磁製 皿に秤り取り, $10^{-2}$ Torr の減圧下, $950^{\circ} \mathrm{C}$ まで昇温した のち, 装置内にアンモニアガスを $1 \mathrm{l} / \mathrm{min}$ で流し, 20〜 30分間活性化した。活性化による試料の重量減少率は木 炭では36\%, PVC 炭では35\%であった。

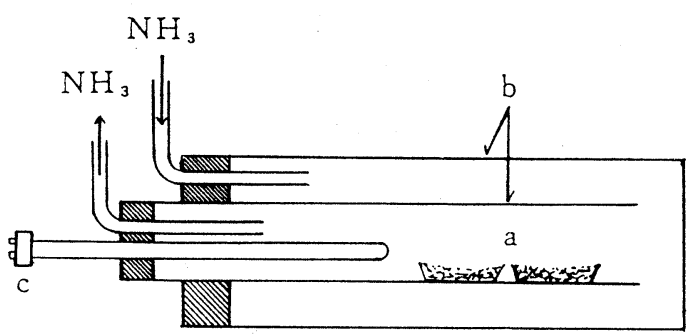

Fig. 1 Apparatus for activation of carbon. a: Sample, b: Silica tubing, c: C-A thermocouple

\section{3 吸着等温線}

水蒸気吸着等温線ならびに活性炭の細孔構造を評価す るためのベンゼン吸着等温線はいずれも石英スプリング バランスを用いる重量法により求めた。試料はあらかじ め, $120^{\circ} \mathrm{C}$ で 2 時間乾燥し，その $0.2 \mathrm{~g}$ を精秤して石英製 バケッ $(10 \mathrm{~mm} \phi \times 15 \mathrm{~mm})$ 亿入れ, さらに $30^{\circ} \mathrm{C}$ の恒温 空気浴中, $10^{-5}$ Torr で 3 時間脱気を行なった。ついで, 真空ラインに水蒸気あるいはベンゼン蒸気を送り，つね に一定圧力になるように調節しながら, 石英スプリング の伸びを読取顕微鏡で追跡し，変化の認められなくなっ た点を吸着平衡とみなして吸着量を求めた。なお，石英 スプリングの感度は $23.2 \mathrm{mg} / \mathrm{mm}$ であった。また，マ ノメー夕封液は水蒸気吸着では $n$-オレイン酸ブチルを, ベンゼン吸着では水銀を用いた。

\section{3. 実験結果と考察}

アンモニアガスで活性化した木炭および PVC 炭のべ ンゼン吸着等温線を Fig. 2 亿示す。乙れをむとに, n 型 BET 式を適用し, Joyner らの方法 ${ }^{6}$ にしたがって単分 子膜容量 $\mathrm{V}_{\mathrm{m}}$, 比表面積 $\mathrm{S}$, 最適の $\mathrm{n}$ 值などを算出した。 ミクロポア容積 $\phi_{\mathrm{m}}$ は Dubinin によるミクロポア充填 の考え方 ${ }^{7)}$ 亿基づき(1)式より求めた。

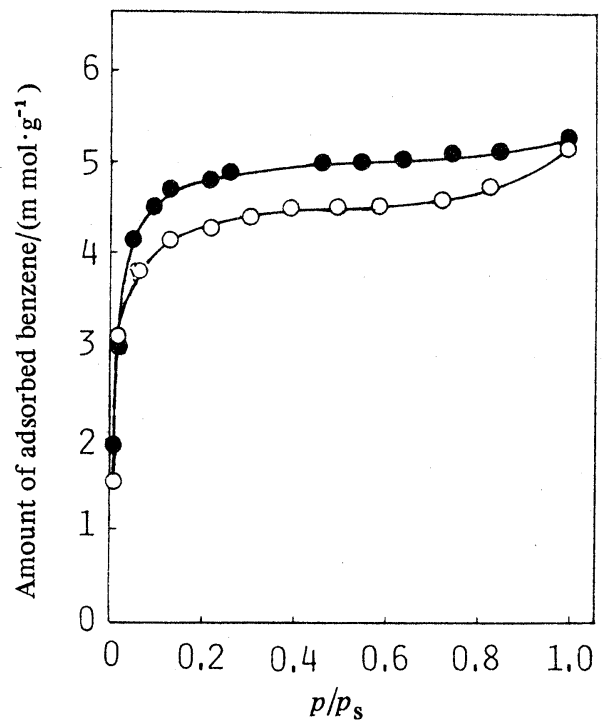

Fig. 2 Benzene adsorption isotherms on activated carbons.

$\bullet$ : Char, O: PVC char

$$
\begin{aligned}
\log a & =C-D\left(\log \frac{p_{\mathrm{S}}}{p}\right)^{2} \\
C & =\log \left(\frac{\phi_{\mathrm{m}}}{v}\right)
\end{aligned}
$$

こてに, $a$ は相対圧 $p / p_{\mathrm{S}}$ での吸着量, $v$ は吸着質の液 体分子容打よび $D$ は定数である。Fig. 2 の吸着等温線 を屯とに $\log a$ と $\left(\log p_{\mathrm{S}} / p\right)^{2}$ との関係をプロットする 之 Fig. 3 を得る。ミクロポア容積 $\phi_{\mathrm{m}}$ は図中の直線部 分を外捜して縦軸との交点を求め, その值から定めた。 得られた特性值を, Table 1 亿示す。表からわかるよう に，木炭試料の単分子膜容量は PVC 炭のそれに比べて いくぶん大きく，したがって比表面積む大きな值を示し ている。一方, 吸着等温線より求まる全細孔容積 $V^{\prime}$ は 両者と屯ほぼ等しく，その大部分がミクロポアで占めら れており，とくに，木炭試料ではその $95 \%$ がミクロポア によるあのであり,てれが比表面積を増大させる結果と なる。nの值は木炭試料では $1.0, \mathrm{PVC}$ 炭試料では 1.2 であり，乙のととはFig. 2 からあわかるように，前者 


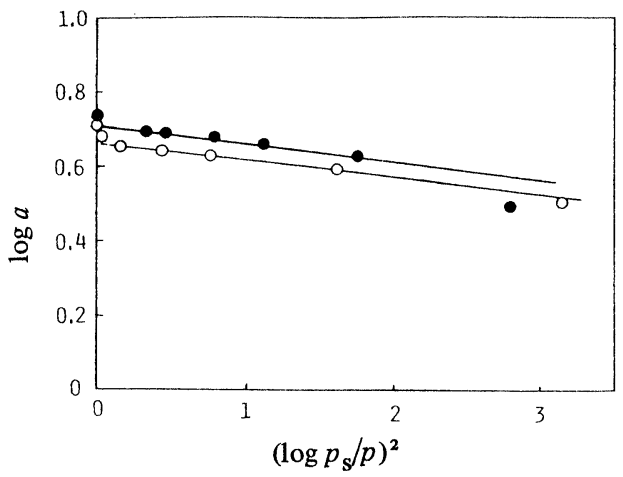

Fig. 3 Dubinin plots for activated carbons. -: Char, O: PVC char

Table 1 Structural characteristics of activated carbons.

\begin{tabular}{c|ccccccc}
\hline \multirow{2}{*}{ Samples } & $V_{\mathrm{m}}$ & $\frac{\mathrm{S}}{\mathrm{m}^{2} \cdot \mathrm{g}^{-1}}$ & $n$ & $\frac{\phi_{\mathrm{m}}}{\mathrm{ml} \cdot \mathrm{g}^{-1}}$ & $\frac{V^{\prime}}{\mathrm{ml} \cdot \mathrm{g}^{-1}}$ & \\
\cline { 2 - 3 } & $\mathrm{m} \mathrm{mol} \cdot \mathrm{g}^{-1}$ & & & & \\
\hline Char & 5.15 & 1437 & 1.0 & 0.444 & 0.469 & 0.947 \\
PVC char & 3.88 & 1083 & 1.2 & 0.397 & 0.459 & 0.865 \\
\hline
\end{tabular}

$\mathrm{PVC}$ 炭試料と屯水蒸気吸着量は低圧部分では相対圧に 比例して, わずかずつ増加し, 中圧部分で急激な立ち上 りを示し，いわゆる $\mathrm{S}$ 字型の等温線を与えている。木炭 試料と PVC 炭試料之を比べると, 前者は後者に比較し て低圧部分での吸着量が多く, 等温線の立ち上りも,よ り低圧側に認められ高圧部分で両者は一致している。活 性炭に対する水蒸気の吸着は, その初期段階において, 活性炭表面存在する表面酸化物依存するといわれて いる ${ }^{8)}$ 。乙のことを確めるため, 原料木炭を試料として, 湿った空気中に, 室温で19日間放置して表面酸化物を増 加させ, 先に述べたと同様の方法で水蒸気吸着等温線を 测定し, 原料炭と比較した。得られた等温線をFig. 5 に 示す。両者の比較から, 表面酸化物の増加は水蒸気吸着 量を增加させ，等温線の立ち上りを低圧 側に移行させ, 試料表面を親水性にして

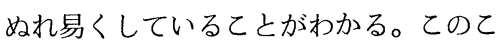
とに関連して,さらに活性炭の表面性質 を知るため, 安息香酸抢よびジフェニル グアニジンの吸着量を各エタノール溶液 から測定し, 活性炭の表面酸化物量を定 量した。測定方法などの詳細については 別に報告した ${ }^{9 !}$ 。その結果, 活性化木炭

では Langmuir 型の, 後者では BET 型の吸着等温線 を与える結果となる。また，nの值は主として試料の細 孔径依存するから，PVC炭では相対的に大きな細孔 が発達しているととになり，したがってミクロポアがい くぶん小さく評価される結果を与えることになる。

木炭扣よび PVC 炭試料の水蒸気吸着等温線の測定結 果を Fig. 4 亿示す。図からわかるように，木炭および

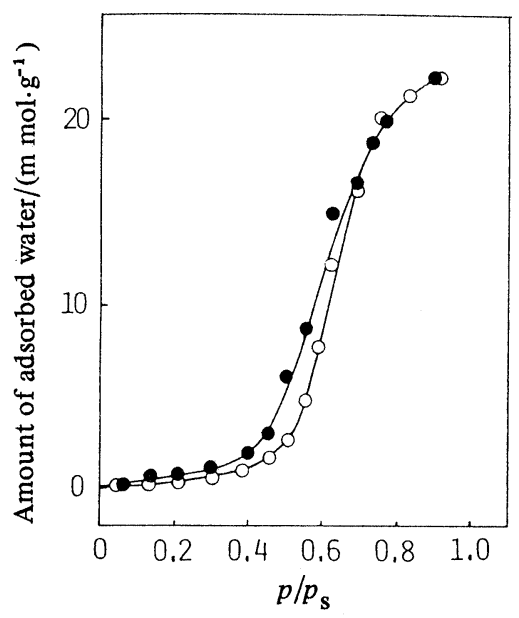

Fig. 4 Water adsorption isotherms on activated carbons. @: Char, O: PVC char
の安息香酸吸着量は $0.63 \mathrm{~m} \mathrm{~mol} / \mathrm{g}$, ジフェニルグアニ

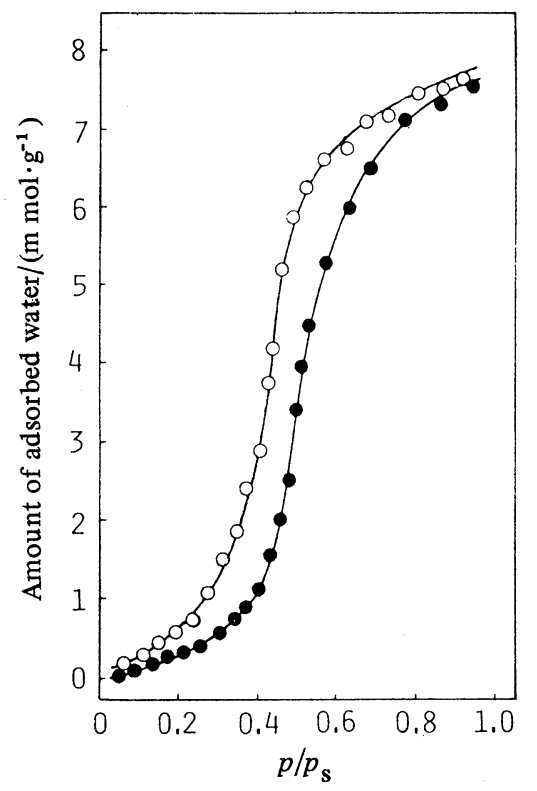

Fig. 5 Water adsorption isotherms on original char.

-: Original char

O: Original char kept in moisture for 19 days 
ジンのそれは $0.53 \mathrm{~m} \mathrm{~mol} / \mathrm{g}$ であり, 活性化 PVC炭で は前者の吸着量は $0.75 \mathrm{~m} \mathrm{~mol} / \mathrm{g}$, 後者のそれは $0.36 \mathrm{~m}$ $\mathrm{mol} / \mathrm{g}$ となった。乙れより活性化試料の表面酸化物の 全量は木炭抢よび PVC 炭とも $1.1 \mathrm{~m} \mathrm{~mol} / \mathrm{g}$ 程度と一定 であるが, PVC炭の場合, 塩基性酸化物の量が酸性酸 化物の量に比べ 2 倍ほど多く, 塩基性に富んだ表面性質 をあつてとがわかる。乙のように活性炭に対する水蒸気 の吸着が表面酸化物に依存すると考えると, 水蒸気吸着 の初期段階では, 乙の表面酸化物の酸素原子が第一の吸 着中心となり,ついで, 吸着した水分子は第二の吸着中 心として, こてでは, 主に水素結合により水分子のクラ スターを形成していくと考えられる ${ }^{10)}$ 。クラスターの成 長は，ついにはそれらが互いに連結, 合体し, 活性炭内 部の微細な細孔を充填する結果となり, こてでは, 水蒸 気の吸着は著しく多くなり, Fig. 4 抢よび 5 にみられる ように，等温線は急激な立ち上りを示すことになる。乙 のような考え方をさらに検討するため, 水蒸気吸着熱を 求めた。試料は活性化木炭を用い, $20^{\circ} \mathrm{C}$ 亿打ける水蒸気 吸着等温線を測定した。得られた結果ならびに先に求め た $30^{\circ} \mathrm{C}$ での等温線をむとに Clausius-Clapeyron式を 適用して吸着熱を算出した。その結果を Fig. 6 亿示す。 図より, 吸着の初期段階, すなわち, 吸着量 $5 \mathrm{~m} \mathrm{~mol} / \mathrm{g}$

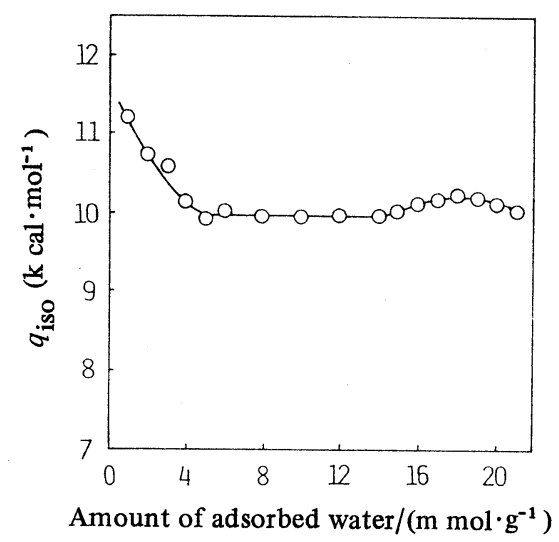

Fig. 6 Isosteric differential heat of adsorption of water on activated char.

までの吸着熱は 10 11 kcal/mol，それ以後は $10 \mathrm{kcal} /$ $\mathrm{mol}$ と一定値を示している。乙のととから, 吸着の初 期では活性点である酸素原子への水分子の吸着という考 え方をとれば, まず, その影響が現われ, さらに吸着が 進めば水分子の凝縮が支配的になると推定される。いい かえるとクラスター形成時では活性点が存在するため, 吸着ポテンシャルが高く, 以後, クラスターが連結, 合 体する時点では水分子の凝縮機構により吸着が進行する
として説明できる。

つぎに, 水蒸気吸着の理論的取り扱いから, 試料表面 に存在する活性点の量を求め, 試料の好性質について 相対的比較を試みた。Dubinin ら ${ }^{8)}$ にれば低相対圧 での水蒸気吸着等温線は(2)式で表わされる。

$$
a=\frac{a_{0} c h}{1-c h}
$$

こてで, $a$ は水蒸気吸着量, $a_{0}$ は第 1 の活性点の量, $c$ は定数, $h$ は相対圧 $\left(p / p_{\mathrm{S}}\right)$ である。乙の式は $h / a$ と $\mathrm{h}$ との関係をプロットすれば直線関係が得られるととを意 味している。また, $c h 《 1$ なる条件では吸着量は相対圧 に比例して増加し, $h=1 / c$ 付近では等温線は急激に立 ち上るてとになる。一例として Fig. 4 の水蒸気吸着等 温線に対し, $h / a$ と $\mathrm{h}$ との関係をプロットした結果を Fig. 7 亿示す。低相対圧部分にバラツキが認められるが, 直線性のよい $0.3 \sim 0.5$ あるいは $0.4 \sim 0.6$ の部分を外挿し, それらの切片および勾配から $\mathrm{a}_{0}$ と $\mathrm{c}$ 值とを定め, 他の

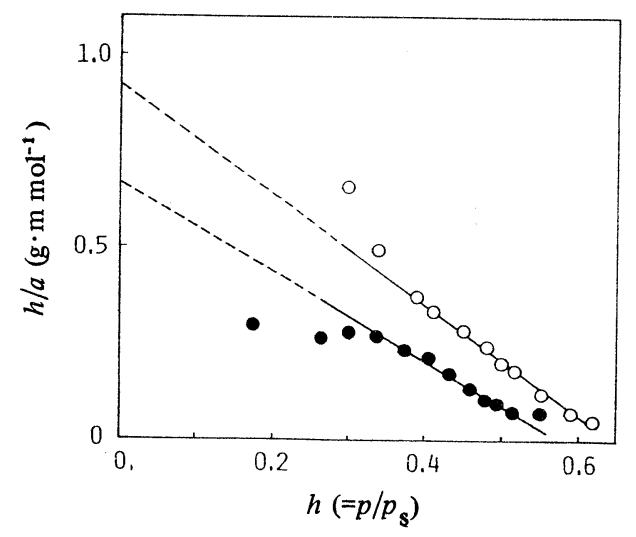

Fig. 7 Water adsorption isotherms in linear form. •: Char, O: PVC char

試料の結果とともに Table 2 亿まとめた。な抢, 活性点 の数 $\mathrm{n}_{0}$ は $a_{0}$ に Avogadro 数を乗ずれば得られる。表 より, 原料木炭を湿った空気中で酸化すると表面酸化物 の量が 2 倍程度増し, また, 活性化によってあかなり増 加しているてとがわかる。しかし, 木炭試料の場合, c 値は三者とも一定値を与えていることから, 主として炭 素材質により定まる定数とみなすことができる。活性化 木炭と PVC 炭との $\mathrm{a}_{0}$ 值を比較すると前者は後者に比 べやや大きく, PVC 炭より親水性でぬれやすいとみら れる。乙てで, 先に酸一塩基の吸着より求めた各試料の 表面酸化物の全量と $a_{0}$ 值とをそれぞれ比較すると, か なりよい一致を示しているととが注目される。すなわち, 表面酸化物量之親疎水性とは密接㑑関しているといえ 
Table 2 Some parameters of water adsorption.

\begin{tabular}{l|cccc}
\hline \multicolumn{1}{c|}{ Samples } & $\frac{a_{0}}{\mathrm{~m} \mathrm{~mol} \cdot \mathrm{g}^{-1}}$ & $\frac{n_{0}}{\mathrm{x} 10^{20} \cdot \mathrm{g}^{-1}}$ & $c$ & $\frac{1}{c}$ \\
\hline Original char 1 & 0.53 & 3.19 & 1.73 & 0.58 \\
Original char 2* & 1.18 & 7.10 & 1.78 & 0.56 \\
Char & 0.79 & 4.76 & 1.78 & 0.56 \\
PVC char & 0.69 & 4.15 & 1.56 & 0.64 \\
\hline
\end{tabular}

* Original char $1 \mathrm{kept}$ in moisture for 19 days

る。したがって，炭素材料表面に存在する酸素を含む官 能基の種類や性質を明らかにして表面酸化物量を定量す れば, その值からぬれやすさを容易に判定するてとがで きる。なお, PVC 炭の $\mathrm{c}$ 值が木炭のそれと異なるのは 上で述べたように炭素材質の違い, あるいは表面酸化物 の種類の相違によるものであろう。

つぎに, 活性炭の細孔構造と好特性との関連性をべ ンゼン抢よび水蒸気吸着等温線に基づいて考察した。 Fig. 8 は活性化木炭あるいは PVC 炭に対するベンゼン

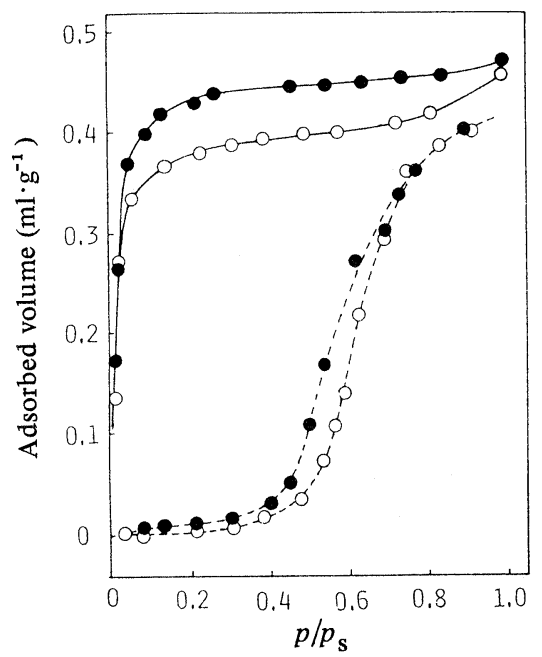

Fig. 8 Relation between adsorbed volume and relative pressure on activated carbons. ๑: Char, ○: PVC char - Benzene adsorption, ... : Water adsorption

および水蒸気吸着等温線より求めた吸着容積と相対圧之 の関係を示したものである。縦軸の吸着容積はそれぞれ の吸着量とベンゼンあるいは水の分子容との積として求 めた。まず, 木炭抢よび PVC炭のベンゼンによる吸着 容積と先に求めたミクロポア容積とを比較すると, 両者
ともほぼB点位置がミクロポア容積に相当してい るととがわかる。一方, 水蒸気吸着はいずれ屯典 型的なS字型の等温線を示し, 木炭試料の場合, その吸着は相対圧の全範井にわたって B 点位置以 下であるととから判断すれば，全てミクロポアで 起っていると考えられる。同様に PVC 炭試料に 扔いても, 水蒸気吸着の大部分はミクロポアで起 り,一部はメソポアおよびマクロポアでの吸着と みなすととができる。このととはTable 1 亿示す ように木炭試料では全細孔のうち, ミクロポアの 占める割合が, $95 \%, \mathrm{PVC}$ 炭試料では87\%であ ることに対応し, また, 前者は後者に比べ $a_{0}$ 值がいく 分大きく現われているてとも関連しているように思われ る。な抢, いずれの試料に扔いても, 高相対圧部分での ベンゼン吸着容積は, 水蒸気吸着容積に比較して, ある 程度大きな值を示すことから，たとえ， $\mathrm{p} / \mathrm{p}_{\mathrm{s}}=1$ に捻い てあメソポアおよびマクロポアが完全に水分子で満され ることはないであろう。

\section{4. 結言}

木炭および PVC 炭を原料とする活性炭の細孔構造之 机特性について検討し,つぎの結果を得た。

アンモニアガスにより活性化した木炭㧍よび PVC 炭 の全細孔の大部分はミクロポアで占められ，とくに，木 炭試料では95\%がミクロポアであった。活性炭に対する 水蒸気吸着等温線は, いずれも典型的な $\mathrm{S}$ 字型曲線で吸 着の初期段階では相対圧に比例して吸着量が増加する。 木炭試料之 PVC 炭試料とを比較すると木炭の方が親水 性でぬれ易い表面をむっている。活性炭のぬれ性質はそ の表面に存在する表面酸化物の量に依存し, その吸着機 構はクラスターモデルおよび水分子の凝集作用により説 明することができる。また, 活性炭のぬれ性質はその細 孔構造にあ依存し, とくにミクロポアが重要な役割を演 じている。以上の知見は活性炭を原料とする酸素電極の ぬれ特性の向上・改善に役立つであろう。

終りに本研究を行うにあたり,で教示を戴いた福井大 学加納源太郎教授に怙礼申し上げます。また, 図面の作 成・レタリングなどに協力してくれた本学大学院生・高 沢知生君に感謝します。

\section{文献}

1) 松田好晴, 山下勝巳, 高須芳雄, 電化 51, 925 (1983)

2) 堀田紀好, 加納源太郎, 野村洋一, 電化 $\mathbf{5 7 , 5 8 2}$ (1989) 
3) 三浦則雄, 後明和幸, 山添 昇, 清山哲郎, 日化 1982,732

4) 古屋長一, 峰尾徳一, 本尾 哲, 電化 55,845 (1987)

5) 加納源太郎, 堀田紀好, 押谷政彦, 水上邦夫, 日化 1974, 2052

6) L.G. Joyner, E.B. Weinberger and C.W. Montgomery, J. Amer. Chem. Soc. 67, 2182 (1945)

7) M.M. Dubinin, "Chemistry and Physics of
Carbon Vol. II" Edited by P.L. Walker, Jr., Marcel Dekker Inc., New York (1966) p. 51

8) M.M. Dubinin, E.D. Zaverina and V.V. Serpinsky, J. Chem. Soc. 1955, 1760

9) 加納源太郎, 堀田紀好, 角谷吉昭, 岡田哲郎, 旭硝 子工業技術奨励会研報 15,989 (1969)

10) H.L. McDermot and J.C. Arnell, J. Phys. Chem. 58, 492 (1954)

\section{改訂・晨秦材料入門}

\section{編集 炭素材料学会 \\ B 5 判 227 頁 $¥ 3,500$ (送料共)}

発行科学技術社

テ113 東京都文京区湯島 $1-5-31$ 第一金森ビル 電話 $03-815-8163$

《目次》

《基礎 編》

1. 炭素の構造

2. 炭素の生成

3. 炭素の黒鉛化

4. 炭素の電子的性質

5. 炭素の熱的性質

6. 炭素の機械的性質

7. 炭素の化学的性質

8. 黒鉛層間化合物
《応 用 編》

9. 炭素の原料

10. 製鉄用コークス

11. 人造黒鉛材

12. カーボン・ブラシ

13. 硬質炭素材

14. カーボンブラック

15. 活 性炭

16. 炭素繊維

17. 炭素繊維強化複合材料 